\title{
PENGARUH REAKSI PASAR ATAS PENGUMUMAN INFORMASI LABA PERUSAHAAN BERKAITAN DENGAN MANAJEMEN LABA PADA PERUSAHAAN MANUFAKTUR DI BURSA EFEK INDONESIA
}

\author{
Oleh \\ Theresia Sri Hastuti ${ }^{1)}$,Henilia Yulita ${ }^{2)}$ \\ Fakultas Ilmu Sosial dan Humaniora Universitas Bunda Mulia \\ email $^{1)}$ :at_gianteti@yahoo.com \\ email2):hyulita@bundamulia.ac.id
}

\begin{abstract}
Financial report is an important factor for inventors to make investment decision in capital market. Publicly financial report which has relevant information will be reacted by market player. Many investors and other users of financial report do not pay attention to the process of publishing financial report, so it pushes the emergence of dysfunctional behaviours like earning management practices.

The research aims to analyze the difference of market reaction between:1) earning management companies and non-earning management companies; 2) income-decreasing discretionary accruals companies and income-increasing discretionary accruals companies.Population of this research is 130 manufactured companies listed in JSX during 2009-2010. Using convenience sampling method, 49 companies were taken to become final samples for each period. The result with two independent samples test Kruskal Walles $\chi($ sign 5\%) shows that there was no difference of market reaction between earning management companies and non-earning management companies ( $\chi$ 0,58989 dan 0,03137), and neither was there between income-decreasing discretionary accruals companies and income-increasing discretionary accruals companies $(\chi 0,735$ dan 2,82767).
\end{abstract}

Keywords : Earning Management, Market Reaction.

Abstrak

Laporan keuangan merupakan faktor penting bagi penemu untuk membuat keputusan di pasar modal. Laporan keuangan publik yang memiliki informasi yang relevan akan bereaksi dengan pemain pasar. Banyak investor dan pengguna lain dari laporan keuangan tidak memperhatikan proses penerbitan laporan keuangan, sehingga mendorong munculnya perilaku disfungsional seperti mendapatkan praktek manajemen.

Penelitian ini bertujuan untuk menganalisis perbedaan reaksi pasar antara: 1) manajemen perusahaan produktif dan perusahaan manajemen non-produktif; 2) penurunan pendapatan perusahaan akrual diskresioner dan peningkatan pendapatan perusahaan akrual diskresioner.

Populasi dari penelitian ini adalah 130 perusahaan manufaktur yang terdaftar di BEJ selama tahun 2009-2010. Menggunakan metode convenience sampling, 49 perusahaan yang diambil menjadi sampel akhir untuk setiap periode. Hasil dengan dua sampel independen menguji Kruskal Walles $\chi$ (tanda 5\%) menunjukkan bahwa tidak ada 
perbedaan reaksi pasar antara perusahaan manajemen laba dan manajemen perusahaanproduktif non $(\chi 0,58989$ Dan 0,03137), dan tidak ada di sana antara akrual diskresioner perusahaan pendapatan menurun dan perusahaan akrual diskresioner pendapatan meningkat $(\chi 0735$ Dan 2,82767).

Kata Kunci : manajemen pendapatan, reaksi pasar

\section{PENDAHULUAN}

Investor sebagai pelaku pasar modal berusaha mencari peluang untuk memperoleh keuntungan besar dalam waktu yang singkat. Sebelum memutuskan untuk berinvestasi, investor harus meramalkan untung ruginya serta mengevaluasi kemungkinan hasil yang akan diterima dari investasi. Informasi yang diperlukan investor diantaranya berupa laporan keuangan yang dipublikasikan. Jika laporan keuangan bermanfaat, maka komponen-komponen yang tersaji dalam laporan keuangan tersebut mempunyai kandungan informasi yang akan direaksi oleh para pelaku pasar.

Manajemen laba (earnings management) merupakan tindakan manajer yang menaikkan atau menurunkan laba yang dilaporkan dari unit yang menjadi tanggung jawabnya dan tidak mempunyai hubungan dengan kenaikan atau penurunan profitabilitas perusahaan jangka panjang. Manajeman laba merupakan area yang kontroversial dan penting dalam akuntansi keuangan. Manajemen laba adalah suatu proses yang dilakukan dengan sengaja dalam batasan General Addopted Accounting Priciples ( GAAP ) untuk mengarah pada tingkatan laba yang dilaporkan.

Penelitian Wahyuningsih menjadi jurnal acuan dalam penelitian ini di mana salah satu dari permasalahan mengenai ukuran perusahaan (size) dihilangkan dengan tujuan untuk menyederhanakan analisis. Penelitian lain tentang reaksi pasar atau yang berhubungan dengan even study dilakukan Telaumbanua (2008), hasil penelitian menunjukkan bahwa investor bereaksi terhadap pengumuman laba perusahaan, bahwa pengumuman laba membawa kandungan informasi ke pasar modal. Investor tidak bereaksi positif terhadap pengumuman laba perusahaan yang labanya turun. Investor bereaksi 
positif terhadap pengumuman laba perusahaan yang labanya turun (Telaumbanua, 2008), Apriani(2007) membuktikan tidak terdapatnya perbedaan harga saham sebelum dan sesudah pengumuman kenaikan atau penurunan dividen, pasar bereaksi kuat terhadap pengumuman kenaikan atau penurunan dividen oleh perusahaan utilitas publik (Apriani, 2007).

Dalam penelitian ini pendekatan akrual digunakan, karena dalam perkembangannya praktek manajemen laba lebih banyak terjadi melalui rekayasa akrual. Hal ini disebabkan akrual merupakan produk utama dari prinsip akuntansi yang diterima umum atau GAAP dan manajemen laba lebih mudah terjadi pada laporan yang berbasis akrual daripada laporan yang berbasis kas (Sulistyanto, 2008). Dengan demikian, pendekatan akrual lebih berpotensi untuk dapat mengungkap praktek manajemen laba.

\section{Telaah Kepustakaan dan} Pengembangan Hipotesis

\footnotetext{
Menurut Schipper (1989:92) mengartikan manajemen laba dari sudut pandang fungsi pelaporan pada
}

pihak eksternal, sebagai disclosure management, dalam pengertian bahwa manajemen melakukan intervensi terhadap proses pelaporan keuangan kepada pihak eksternal dengan tujuan untuk memperoleh keuntungan pribadi. Scott (1997) mendefinisikan manajemen laba sebagai berikut, "Given that manajers can choose accounting policies from a set (for example, $G A A P)$, it is natural to expect that they wiil choose policies so as to maximize their own utility and or the market value of the firm." Dari definisi tersebut dapat dijelaskan bahwa manajemen laba merupakan pemilihan kebijakan akuntansi oleh manajer dari standar akuntansi yang ada dan secara alamiah dapat memaksimumkan utilitas mereka dan atau nilai pasar perusahaan.

Manajemen laba sebagai suatu proses mengambil langkah yang disengaja dalam batas prinsip akuntansi yang diterima General Accepted Accounting Princisp (GAAP). Faktor-faktor yang mempengaruhi manajemen laba oleh Watt dan Zimmerman dalam Sugiri (1998) sebagai berikut: 


\section{1) Bonus Plan Hypothesis}

Bahwa pada perusahaan dengan bonus plan cenderung menggunakan metode akuntansi yang meningkatkan income saat ini.

2) Debt To Equity Hypothesis

Bahwa pada perusahaan yang mempunyai rasio debt to equity besar mana manajer perusahaan tersebut cenderung menggunakan metode akuntansi yang akan meningkatkan pendapatan atau laba.

\section{3) Political Cost Hypothesis}

Bahwa pada perusahaan besar yang kegiatan operasionalnya menyentuh sebagian besar masyarakat akan cenderung untuk mengurangi laba yang dilaporkan.

Selain tiga faktor yang dikemukakan oleh Watts dan Zimmerman dalam Sugiri (1998) Scott (2000) mengemukakan beberapa faktor lain yang memotivasi terjadinya manajemen laba yaitu Taxation Motivation, Pergantian CEO, dan Initial Public Offering (IPO). Bentuk-bentuk manajemen laba yang dikemukakan oleh Scott (2000:383) yaitu :

\section{1) Taking a bath}

Manajemen melakukan metode taking a bath dengan mengakui biaya-biayadan kerugian periode yang akan datang pada periode berjalan ketika pada periode berjalan terjadi keadaan buruk yang tidak menguntungkan.

\section{2) Income minimization}

Manajer melakukan praktik manajemen laba berupa income minimization dengan mengakui secara lebih cepat biaya-biaya, seperti biaya pemasaran, riset dan pengembangan, ketika perusahaan memperoleh profit yang cukup besar dengan tujuan untuk mengurangi perhatian politis.

\section{3) Income maximization}

Income maximation merupakan upaya manajemen untuk memaksimalkan laba yang dilaporkan.

4) Income smoothing

Income smoothing merupakan praktik manajemen laba yang dilakukan dengan menaikkan atau menurunkan laba, dengan 
tujuan untuk mengurangi

fluktuasi laba yang dilaporkan, sehingga perusahaan tampak lebih stabil dan tidak beresiko.

Dalam penelitian ini, discretionary accruals sebagai proksi atas manajemen laba diukur dengan menggunakan Model Kasznik. Model Jones dan Modifikasi Model Jones belum diyakini dapat memisahkan komponen akrual non diskresioner dan akrual diskresioner dengan tepat, karena model Jones dan modifikasinya mempunyai nilai adjusted $R 2$ yang rendah. Sehingga ada kemungkinan kesalahan pengklasifikasian akrual non diskresioner dan akrual diskresioner (Siregar dan Utama, 2005).

Fama (1970) dalam Samsul (2006:270 ) membagi efisiensi pasar ke dalam tiga bentuk utama berdasarkan informasi sebagai berikut:

1) Efisiensi pasar bentuk lemah (the weak efficient market hypothesis)

Pasar dikatakan efisien dalam bentuk lemah jika harga-harga dari sekuritas tercermin secara penuh (fully reflect) informasi masa lalu. Dengan demikian, nilai-nilai masa lalu tidak dapat digunakan untuk memprediksi harga sekarang.

2) Efisiensi pasar bentuk setengah kuat (the semistrong efficient market hypothesis)

Pasar dikatakan efisien setengah kuat jika harga-harga sekuritas secara penuh mencerminkan (fully reflect) semua informasi yang dipublikasikan (all publicly available information), termasuk informasi yang berada pada laporan keuangan perusahaan emiten.

3) Efisiensi pasar bentuk kuat (the strong efficient market hypothesis)

Pasar dikatakan efisien kuat jika harga-harga sekuritas secara penuh mencerminkan (fully reflect) semua informasi yang tersedia, termasuk informasi yang privat.

Reaksi pasar atas informasi yang disampaikan oleh perusahaan ditunjukkan dengan adanya perubahan harga saham perusahaan yang bersangkutan. Reaksi ini dapat 
diukur dengan menggunakan return sebagai nilai perubahan harga atau dengan menggunakan return tidak normal (abnormal return). Jika digunakan abnormal return, maka dapat dikatakan bahwa suatu pengumuman laba yang mempunyai kandungan informasi akan memberikan abnormal return kepada pasar. Sebaliknya yang tidak mengandung informasi tidak akan memberikan abnormal return kepada pasar (Jogiyanto, 2000).

Abnormal return atau excess return merupakan selisih return yang sesungguhnya terjadi dengan return normal. Return normal merupakan return ekspektasi (return yang diharapkan oleh investor). Dengan demikian abnormal return merupakan selisih antara return sesungguhnya yang terjadi dengan return ekspektasi. Sedangkan Cummulative Abnormal Return (CAR) merupakan penjumlahan dari abnormal return hari sebelumnya di dalam periode peristiwa untuk masing-masing sekuritas (Jogiyanto, 2000). Return tidak normal (abnormal return), yang merupakan selisih antara return sesungguhnya yang terjadi dengan return ekspektasi.

Return ekspektasi dihitung dengan menggunakan model pasar (market model). Sebenarnya terdapat beberapa model untuk menghitung return ekspektasi, tetapi dalam penelitian ini perhitungan return ekspektasi dilakukan dengan menggunakan model pasar karena dalam kenyataannya sekuritas berkovarian atau berkorelasi satu dengan yang lainnya.

Penelitian Ball \& Brown (1968) menyatakan harga saham akan cenderung naik jika laba sesuai harapan dan harga saham akan cenderung turun jika laba yang dilaporkan lebih kecil dari harapan. Praktek manajemen laba terlihat dalam penyajian laporan keuangan menyebabkan informasi yang terdapat dalam laporan keuangan tidak mencerminkan kondisi perusahaan yang sebenarnya. Dengan melalui manajemen laba, manajer dapat mengatur angka-angka laba yang dilaporkan agar sesuai kepentingan pribadinya maupun perusahaan. Kondisi ini bisa menyesatkan investor dalam 
mengestimasi return yang diinginkan.

Hasil penelitian Assih (2000) mengindikasikan bahwa di sekitar tanggal pengumuman laba, cummulative abnormal return (CAR) untuk perusahaan perata laba lebih rendah dari perusahaan bukan perata dan perbedaannya tersebut signifikan. Berdasarkan penjelasan di atas, dapat dinyatakan dalam hipotesis sebagai berikut :

\section{H 1 : Cummulative abnormal} return perusahaan yang melakukan manajemen laba lebih kecil dari pada Cummulative abnormal return perusahaan yang tidak melakukan menajemen laba.

\section{Income}

increasing

discretionary accruals terkait dengan sinyal manajemen mengenai kondisi perusahaan saat ini yang lebih buruk dari yang dilaporkan. Apabila perusahaan melakukan pemilihan akrual diskresioner yang menyebabkan terjadinya kenaikan laba, pelaku pasar akan bereaksi secara negatif, karena informasi laba tersebut mencerminkan kinerja perusahaan yang diperkirakan buruk. Perusahaan mempunyai akrual diskresioner menaikkan laba, pelaku pasar akan memberi reaksi yang lebih rendah dibandingkan perusahaan yang mempunyai akrual diskresioner menurunkan laba, abnormal return atas informasi laba dari perusahaan yang mempunyai akrual diskresioner menaikkan laba juga menjadi lebih kecil. Berdasarkan penjelasan di atas, maka dapat dinyatakan hipotesis sebagai berikut :

$\boldsymbol{H} 2$ : Cummulative abnormal return antara perusahaan yang mempunyai akrual diskresioner menaikkan laba (income increasing discretionary accruals) lebih kecil dari pada Cummulative abnormal return perusahaan yang mempunyai akrual diskresioner menurunkan laba (income decreasing discretionary accruals).

\section{METODE PENELITIAN}

Dalam penelitian ini untuk menyelesaikan permasalahan melalui dua (2) tahap, yaitu tahap pertama menjelaskan manajemen laba dengan menggunakan Kasznik Model, tahap kedua menjelaskan mengenai even 
study dengan market model. Penelitian membutuhkan data panel yang terdiri dari data time series 3 tahun dan data cross section yang jumlahnya sesuai dengan kriteria yang ditetapkan untuk convenient sampling. Data berkala (time series data) adalah data yang dikumpulkan dari waktu ke waktu untuk mengetahui perkembangan suatu hal atau kegiatan, cross section data yaitu data yang dikumpulkan pada suatu waktu tertentu (at a point of time) untuk menggambarkan keadaan atau kegiatan pada waktu yang bersangkutan (Supranto: 2010). Penelitian tahap pertama terdiri dari beberapa langkah.

Langkah pertama yaitu dengan meregresikan Kasznik Model,

ACCRit $=\alpha 0+[\Delta$ REVit $-\triangle R E C i t]$

$\alpha 1+\alpha 2$ PPEit $+\triangle$ CFOit $\alpha 3+$ eit

Langkah kedua mengestimasikan variabel dependen dengan menghitung non-discretionary accrual (NDAit) dengan cara estimasi variabel dependen: NDAit $=$ $\alpha 0+[\Delta$ REVit - $\triangle$ RECit $] \quad \alpha 1+$ $\alpha 2$ PPEit $+\triangle$ CFOit $\alpha 3$

Langkah ketiga menghitung discretionary accrual (DAit) dengan cara menghitung residual yaitu aktual dari variabel dependen dikurangi dengan estimasi variabel dependen. Discretionary accrual (DAit) merupakan selisih antara total akrual (TAit) dengan nondiscretionary accrual (NDAit). DAit = ACCRit - NDAit. Langkah keempat melakukan uji - $\mathrm{t}$ untuk satu sampel, uji stasistik dari distribusi sampling dimana mean dari sampel $\mathrm{x}$ dan deviasi standar dari sampel s, maka:

$$
t=\frac{\bar{x}-\mu}{s \sqrt{ } n}
$$

di mana :

$$
\begin{aligned}
& \mathrm{n}=\text { ukuran sampel } \\
& \mu=\text { mean dari populasi }
\end{aligned}
$$

Untuk menguji residual $=\mathrm{DA}$ dari persamaan Kasznik Model, maka:

$$
\begin{aligned}
& \mathrm{H}_{0}: \mu=0 \text { artinya } \mathrm{CAR}=0 \\
& \text { pengumuman laba tidak } \\
& \text { mengandung informasi. } \\
& \text { Ha: } \neq \neq 0 \text { artinya CAR } \neq 0 \\
& \text { pengumuman laba mengandung } \\
& \text { informasi. }
\end{aligned}
$$

Kriteria penolakan $\mathrm{H}_{0}$, - $\mathrm{t} \square_{/ 2, \mathrm{n}-1}>\mathrm{t}>$ $\mathrm{t} \square_{/ 2, \mathrm{n}-1,}, \square$ adalah taraf signifikan $5 \%$, n-1 adalah derajat kebebasan. Langkah kelima diantara perusahaan 
yang melakukan manajemen laba, apabila DA $=$ positif berarti increasing earning sedangkan apabila DA $=$ negatif berarti decreasing earning.

Penelitian tahap kedua menghitung cummulative abnormal return (CAR), abnormal return atau excess return merupakan selisih return yang sesungguhnya terjadi dengan return normal. Return normal merupakan return ekspektasi (return yang diharapkan oleh investor). Dengan demikian abnormal return merupakan selisih antara return sesungguhnya yang terjadi dengan return ekspektasi (Samsul, 2008). Untuk menghitung return ekspektasi, dalam penelitian ini digunakan model pasar (market model), yang telah dirumuskan pada rumus ke-14 tersebut di atas sebagai berikut :

$E\left(R_{i t}\right)=\alpha i+\beta i \cdot R M_{j}$

dimana,

E ( $\mathrm{R}$ it):return ekspektasi sekuritas ke-i untuk peristiwa ke-t ai $\quad$ intersep untuk sekuritas ke i $\beta \quad$ : koefisien slope yang merupakan beta dari sekuritas ke-i
$\mathrm{R}_{\mathrm{j}}$ :return indeks pasar pada periode estimasi ke $\mathrm{j}$

Market model digunakan untuk semua perusahaan yang terpilih sebagai pada periode tahunan. Dalam penelitian ini digunakan Cummulative Abnormal Return (CAR) untuk mengetahui reaksi pasar atas pengumuman informasi laba. CAR merupakan penjumlahan dari abnormal return hari sebelumnya di dalam periode peristiwa (event window) untuk masing-masing sekuritas (Samsul, 2008). Cummulative Abnormal Return (CAR) tersebut dapat dirumuskan sebagai berikut:

$$
\begin{aligned}
C_{2} R_{i(t, t 2)} \quad: \sum A R_{i t} & \\
& \mathrm{t}=\mathrm{t}_{1}
\end{aligned}
$$

dimana,

$$
\mathrm{CAR}_{\mathrm{i}(11,2) \quad: \quad \text { Cummulative }}
$$
Abnormal Return untuk perusahaan i dari periode $t_{1}$ sampai dengan $t_{2}$ $\mathrm{AR}_{\mathrm{it}}$ : Return tidak normal (abnormal retun) sekuritas ke-i pada periode peristiwa ke-t, yang telah dirumuskan pada rumus ke-9 tersebut di atas sebagai berikut: 


$$
\mathrm{AR}_{i t}=\mathrm{R}_{\text {it }}-\mathrm{E}\left(\mathrm{R}_{\mathrm{it}}\right)
$$

dimana,

$\mathrm{R}$ it: return sesungguhnya yang terjadi untuk sekuritas ke- i pada periode peristiwa ke-t

E $\left(\mathrm{R}_{\mathrm{it}}\right)$ : return ekspektasi sekuritas

ke-i untuk periode peristiwa ke-t

$t_{1}$ : awal periode observasi

$\mathrm{t}_{2}$ : akhir periode observasi

Menghitung CAR dengan menggunakan return windows dimulai dari -5 dan berakhir +5 , yaitu lima hari sebelum tanggal pengumuman sampai lima hari setelah tanggal pengumuman.

Windows lima hari sebelum tanggal pengumuman mempunyai tujuan untuk mengantisipasi adanya kemungkinan diketahuinya informasi oleh sebagian investor sebelum informasi diumumkan, dan windows lima hari sesudah tanggal pengumuman dipertimbangkan sudah cukup untuk mengakumulasi pengaruh pengumuman laba pada harga saham sebelum harga saham dipengaruhi oleh peristiwa lain (Samsul, 2008). Untuk menguji CAR dengan menggunakan Kruskal-
Wallis test dengan rumus (Warrack, 2003)

$$
\begin{aligned}
& \mathrm{H} \\
& (\mathrm{n}+1) \\
& \mathrm{j}=1
\end{aligned}
$$

\section{ANALISIS DAN PEMBAHASAN}

Hasil Penelitian Tahap I

Penelitian pada tahap pertama yaitu untuk mengetahui perusahaan melakukan manajemen laba atau tidak melakukan manajemen laba dengan menggunakan Kaszik Model memperoleh persamaan regresi berikut ini:

Tahun 2009

$$
\begin{aligned}
& \text { ACCRit }=\alpha 0+[\Delta R E V i t-\triangle R E C i t] \\
& 0,140+-0,159 P P E i t+\Delta \text { CFOit }^{-} 0,665
\end{aligned}
$$

Tahun 2010

$$
\begin{aligned}
& \text { ACCRit }=\alpha 0+[\triangle \text { REVit }-\triangle R E C i t] \\
& 0,129+\quad-0,019 P P E i t+\quad \triangle C F O i t \quad- \\
& 1,060
\end{aligned}
$$

Berdasarkan persamaan regresi dapat diketahui nilai residual yaitu discretionary accrual (DA). Dari nilai DA dapat diperoleh t-hitung, kemudian dibandingkan dengan nilai t-tabel untuk mengetahui tingkat signifikan.

Tabel 1 
Hasil Penelitian Tahap I

\begin{tabular}{|c|c|c|c|c|}
\hline Thn & Perusahaan & Residual & Uji- t & Keterangan \\
\hline \multirow[t]{5}{*}{2009} & KIAS & $-9, E+10$ & $-0,4732940$ & $\begin{array}{l}\text { Tidak signifikan, tidak } \\
\text { melakukan manajemen laba }\end{array}$ \\
\hline & GDYR & $\begin{array}{l}- \\
1,60 \mathrm{E}+11\end{array}$ & $-0,8741495$ & $\begin{array}{l}\text { Tidak signifikan, tidak } \\
\text { melakukan manajemen laba }\end{array}$ \\
\hline & ALMI & $3,11 \mathrm{E}+11$ & $-1,6989341$ & $\begin{array}{l}\text { Signifikan, melakukan income } \\
\text { decreasing }\end{array}$ \\
\hline & YAMA & $\begin{array}{l}- \\
3,26 \mathrm{E}+11\end{array}$ & $-1,7856099$ & $\begin{array}{l}\text { Signifikan, melakukan income } \\
\text { decreasing }\end{array}$ \\
\hline & UNGGUL & $2,67 \mathrm{E}+11$ & 1,4591464 & $\begin{array}{l}\text { Signifikan, melakukan income } \\
\text { increasing }\end{array}$ \\
\hline \multirow[t]{5}{*}{2010} & ASTO & $4,38 \mathrm{E}+11$ & 1,48676590 & $\begin{array}{l}\text { Signifikan, melakukan income } \\
\text { increasing }\end{array}$ \\
\hline & INDOM & $\begin{array}{l}- \\
7,99 \mathrm{E}+11\end{array}$ & $\begin{array}{l}- \\
2,71388314\end{array}$ & $\begin{array}{l}\text { Signifikan, melakukan income } \\
\text { decreasing }\end{array}$ \\
\hline & MANDOM & $\begin{array}{l}- \\
1,83 \mathrm{E}+09\end{array}$ & $\begin{array}{l}- \\
0,00621755\end{array}$ & $\begin{array}{l}\text { Tidak signifikan, tidak } \\
\text { melakukan manajemen laba }\end{array}$ \\
\hline & LIONM & $7,75 \mathrm{E}+10$ & 0,26322057 & $\begin{array}{l}\text { Tidak signifikan }, \text { tidak } \\
\text { mealukan manajemen lama }\end{array}$ \\
\hline & INDO & $1,10 \mathrm{E}+11$ & 0,37309572 & $\begin{array}{l}\text { Tidak signifikan, tidak } \\
\text { melakukan manajemen laba }\end{array}$ \\
\hline
\end{tabular}

Sumber: data sekunder diolah, 2012

yang diperoleh dari periode estimasi

\section{Hasil Penelitian Tahap II}

Penelitian tahap kedua yaitu untuk mencari nilai cummulativ abnormal return (CAR) perusahaan selama periode jendela ( -5 sampai dengan hari +5$)$ dengan menggunakan persamaan market
(-35 sampai dengan -6). Kemudian diuji dengan menggunakan KruskalWallis test. Hasil penelitian tahap kedua yaitu menguji nilai CAR antara perusahaan yang melakukan manajemen laba dengan perusahaan yang tidak melakukan manajemen 
laba hasilnya dapat dilihat dalam

Tabel 2.

Tabel 2

Rangking CAR Perusahaan Manajemen Laba dan Tidak

\begin{tabular}{|c|c|c|c|c|c|c|c|}
\hline \multirow[t]{2}{*}{$\mathrm{NO}$} & \multirow{2}{*}{ NAMA PERUSAHAAN } & \multicolumn{3}{|l|}{2009} & \multicolumn{3}{|l|}{2010} \\
\hline & & CAR & YA & TDK & CAR & YA & TIDAK \\
\hline 1 & KERAMIKA INDONESIA(1) & $-0,363524$ & & 1 & $-0,013812$ & & 18 \\
\hline 2 & GOODYEAR INDONESIA(2) & $-0,118572$ & & 9 & 0,107007 & 43 & \\
\hline 3 & $\begin{array}{l}\text { ALAKASA } \\
\text { INDUSTRINDO(3) }\end{array}$ & 0,036356 & 38 & & $-0,462058$ & & 2 \\
\hline 4 & ALUMINDO LIGHT M(4) & $-0,041476$ & 16 & & 0,236426 & 47 & \\
\hline 5 & ASTRA INTERNASIONAL(5) & 0,151587 & 48 & & $-1,320475$ & & 1 \\
\hline 6 & YAMA PRIMA HASTA(6) & 0,003007 & 30 & & $-0,038283$ & & 14 \\
\hline 7 & EVER SHINE(7) & $-0,073944$ & 11 & & $-0,047026$ & & 13 \\
\hline 8 & MULTI BINTANG INDO(8) & $-0,000706$ & 27 & & $-0,000145$ & & 22 \\
\hline 9 & UNGGUL INDAH CAH(9) & 0,079488 & 44 & & $-0,009733$ & 19 & \\
\hline 10 & ASTRA OUTO PART(10) & 0,012875 & & 33 & 0,081966 & 40 & \\
\hline 11 & INDOMOBIL SUKSES(11) & $-0,009310$ & 25 & & $-0,212900$ & 4 & \\
\hline 12 & MANDOM INDONESIA(12) & $-0,023681$ & 20 & & $-0,022905$ & & 16 \\
\hline 13 & LION MESHPRIMA(13) & 0,023482 & 36 & & $-0,136112$ & & 6 \\
\hline 14 & INDO ACIDATAMA(14) & $-0,015542$ & 21 & & 0,193810 & & 45 \\
\hline 15 & MALINDO FEEDMILL(15) & $-0,040201$ & 17 & & 0,001526 & & 25 \\
\hline 16 & BUDI ACID JAYA(16) & $-0,082916$ & & 10 & 0,032350 & & 33 \\
\hline 17 & DARIA VARIA(17) & 0,042297 & 40 & & $-0,372537$ & & 3 \\
\hline 18 & INDOFOOD SUKSES M(18) & $-0,237548$ & 5 & & 0,042107 & & 37 \\
\hline 19 & BENTUL INDONESIA(19) & $-0,144501$ & 8 & & $-0,211150$ & & 5 \\
\hline 20 & MULIA INDUSTRINDO(20) & $-0,284923$ & 4 & & $-0,133718$ & 7 & \\
\hline 21 & HM SAMPURNA(21) & $-0,060942$ & 13 & & $-0,095783$ & 8 & \\
\hline 22 & BARITO PASIFIK(22) & 0,058932 & 42 & & 0,073144 & 39 & \\
\hline 23 & $\begin{array}{l}\text { ARWANA CITRA } \\
\operatorname{MULIA(23)}\end{array}$ & $-0,187514$ & 7 & & 0,065584 & & 38 \\
\hline 24 & ARGO PANTES(24) & $-0,009605$ & & 24 & $-0,027452$ & & 15 \\
\hline 25 & PAN BROTHERS(25) & 0,091933 & 45 & & 0,039611 & & 36 \\
\hline 26 & SELAMAT SEMPURNA(26) & 0,075610 & 43 & & $-0,052549$ & & 11 \\
\hline 27 & MUSTIKA RATU(28) & $-0,027132$ & 19 & & $-0,071401$ & & 9 \\
\hline 28 & BERLINA (29) & $-0,007901$ & 26 & & 0,037248 & & 34 \\
\hline 29 & TITAN KIMIA(30) & $-0,311946$ & 3 & & 0,021829 & 31 & \\
\hline 30 & UNILEVER(31) & 0,022897 & 35 & & $-0,047885$ & 12 & \\
\hline 31 & KABELINDO (32) & $-0,030291$ & 18 & & 0,002991 & & 26 \\
\hline 32 & SEMEN GRESIK(33) & $-0,070405$ & 12 & & $-0,014647$ & 17 & \\
\hline
\end{tabular}




\begin{tabular}{|r|l|r|r|r|r|r|r|}
33 & SEKAR LAUT(34) & 0,106123 & 46 & & $-0,004245$ & 20 \\
\hline 34 & MAYORA INDAH(35) & 0,058732 & & 41 & 0,187724 & 44 & \\
\hline 35 & LION METAL WORK(36) & $-0,045122$ & 15 & & 0,235944 & & 46 \\
\hline 36 & MULTI STRADA (37) & $-0,013047$ & & 23 & 0,295009 & & 48 \\
\hline 37 & KEDAUNG INDAH CAN(38) & 0,011856 & 32 & & $-0,002416$ & & 21 \\
\hline 38 & UNITEX(39) & $-0,357900$ & 2 & & 0,000048 & & 24 \\
\hline 39 & ASIA PACIFIK FIBER(40) & 0,015560 & 34 & & 0,039509 & 35 & \\
\hline 40 & SURYA INTRINDO(41) & 0,002917 & 29 & & 0,000000 & & 23 \\
\hline 41 & ASAHIMAS (42) & $-0,059126$ & 14 & & 0,101994 & & 42 \\
\hline 42 & GUDANG GARAM(43) & $-0,218137$ & 6 & & $-0,063935$ & 10 & \\
\hline 43 & CHAROEN P(44) & 0,038511 & 39 & & 0,019779 & & 29 \\
\hline 44 & SORINI AGRO ASIA(45) & 0,011315 & & 31 & 0,020341 & & 30 \\
\hline 45 & TEMBAGA MULIA S (46) & 0,032857 & & 37 & 0,011235 & 27 & \\
\hline 46 & ULTRA JAYA (47) & 0,785071 & & 49 & 0,378282 & & 49 \\
\hline 47 & KIMIA FARMA (48) & $-0,013688$ & 22 & & 0,083101 & & 41 \\
\hline 48 & SUPARMA(49) & 0,001516 & & 28 & 0,024189 & & 32 \\
\hline 49 & ARGA KARYA PRIMA(50) & 0,122654 & & 47 & 0,017609 & & 28 \\
\hline & Jumlah T & & 892 & 333 & & 383 & 842 \\
\hline
\end{tabular}

Sumber: data sekunder diolah,2012

Kruskal-Wallis test untuk perusahaan yang melakukan manajemen laba dan tidak melakukan manajemen laba.

\section{2}

$\mathrm{H}=\left\{12 / \mathrm{n}(\mathrm{n}+1) \sum \mathrm{Tj}^{2} / \mathrm{nj}\right\}-3$ $(\mathrm{n}+1)$

$j=1$

$=\left\{12 / 49(49+1)\left(333^{2} / 12+892^{2}\right.\right.$

/37) - $3(49+1)$

$=\{12 / 2450(9240,75$

$+21504,43)-150$

$=(0,004898 \times 30745,18)-150$

$=150,58989-150$

$=0,58989$
$\mathrm{H}=\left\{12 / \mathrm{n}(\mathrm{n}+1) \sum \mathrm{Tj}^{2} / \mathrm{nj}\right\}-3$ $(\mathrm{n}+1)$

$\mathrm{j}=1$

$$
=\left\{12 / 49(49+1)\left(383^{2} / 15+892^{2}\right.\right.
$$

/34) - $3(49+1)$

$=\{12 / 2450(9779,27$

$+20851,88)-150$

$=(0,004898 \times 30631,15)-150$

$=150,03137-150$

$=0,03137$

Berdasarkan perhitungan untuk mengetahui CAR antara perusahaan yang melakukan manajemen laba dengan perusahaan yang tidak 
melakukan manajemen laba

diperoleh hasil nilai $\chi$-hitung sebesar 0,58989 dan 0,03137 sedangkan nilai $\chi$-tabel sebesar 3,84146. Jadi nilai $\chi$-hitung dengan tingkat signifikan 0,05 antara nilai hasil lebih kecil dibandingkan dengan nilai $\chi$-tabel yaitu $\mathrm{H}<\chi^{2}, \mathrm{k}-1$ maka Ho tidak ditolak berarti nilai CAR untuk kedua kelompok sampel tidak terdapat perbedaan.

Kruskal-Wallis test untuk perusahaan yang melakukan manajemen laba menaikkan dan menurunkan laba.

$$
\begin{aligned}
& \begin{array}{l}
\mathrm{H} \\
(\mathrm{n}+1)
\end{array} \\
& \begin{aligned}
& \mathrm{j}=1 \\
&=\left\{12 / \mathrm{n}(\mathrm{n}+1) \sum \mathrm{Tj} 2 / \mathrm{nj}\right\}-3 \\
&2 / 27)- 3(37+1) \\
& \quad=\{12 / 1406(2464,9 \\
&+11041,33)-114
\end{aligned}
\end{aligned}
$$$$
=(0,0085349 \times 30745,18)-
$$

114

$$
\begin{aligned}
& =116,82767-114 \\
& =2,8276
\end{aligned}
$$

Tabel 3

Rangking CAR Perusahaan Menaikkan dan Menurunkan Laba

\begin{tabular}{|r|l|r|r|r|}
\hline \multirow{2}{*}{ NO } & \multirow{2}{*}{ NAMA PERUSAHAAN } & \multicolumn{2}{|c|}{2010} \\
\cline { 3 - 5 } & & CAR & Naik & Turun \\
\hline 1 & ALAKASA INDUSTRINDO(3) & 0,036356 & & 29 \\
\hline 2 & ALUMINDO LIGHT M(4) & $-0,041476$ & & 13 \\
\hline 3 & ASTRA INTERNASIONAL(5) & 0,151587 & & 37 \\
\hline 4 & YAMA PRIMA HASTA(6) & 0,003007 & & 24 \\
\hline 5 & EVER SHINE(7) & $-0,073944$ & & 8 \\
\hline 6 & MULTI BINTANG INDO(8) & $-0,000706$ & & 22 \\
\hline 7 & UNGGUL INDAH CAH(9) & 0,079488 & 34 & \\
\hline 8 & INDOMOBIL SUKSES(11) & $-0,009310$ & & 20 \\
\hline 9 & MANDOM INDONESIA(12) & $-0,023681$ & & 17 \\
\hline 10 & LION MESHPRIMA(13) & 0,023482 & & 28 \\
\hline 11 & INDO ACIDATAMA(14) & $-0,015542$ & & 18 \\
\hline 12 & MALINDO FEEDMILL(15) & $-0,040201$ & & 14 \\
\hline 13 & DARIA VARIA(17) & 0,042297 & & 31 \\
\hline 14 & INDOFOOD SUKSES M(18) & $-0,237548$ & 4 & \\
\hline 15 & BENTUL INDONESIA(19) & $-0,144501$ & & 7 \\
\hline 16 & MULIA INDUSTRINDO(20) & $-0,284923$ & 3 & \\
\hline
\end{tabular}




\begin{tabular}{|c|c|c|c|c|}
\hline 17 & HM SAMPURNA(21) & $-0,060942$ & & 10 \\
\hline 18 & BARITO PASIFIK(22) & 0,058932 & 32 & \\
\hline 19 & ARWANA CITRA MULIA(23) & $-0,187514$ & & 6 \\
\hline 20 & PAN BROTHERS(25) & 0,091933 & & 35 \\
\hline 21 & SELAMAT SEMPURNA(26) & 0,075610 & & 33 \\
\hline 22 & MUSTIKA RATU(28) & $-0,027132$ & & 16 \\
\hline 23 & BERLINA (29) & $-0,007901$ & & 21 \\
\hline 24 & TITAN KIMIA(30) & $-0,311946$ & 2 & \\
\hline 25 & UNILEVER(31) & 0,022897 & 27 & \\
\hline 26 & KABELINDO (32) & $-0,030291$ & & 15 \\
\hline 27 & SEMEN GRESIK(33) & $-0,070405$ & 9 & \\
\hline 28 & SEKAR LAUT(34) & 0,106123 & & 36 \\
\hline 29 & LION METAL WORK(36) & $-0,045122$ & & 12 \\
\hline 30 & KEDAUNG INDAH CAN(38) & 0,011856 & & 25 \\
\hline 31 & UNITEX(39) & $-0,357900$ & & 1 \\
\hline 32 & ASIA PACIFIK FIBER(40) & 0,015560 & & 26 \\
\hline 33 & SURYA INTRINDO(41) & 0,002917 & & 23 \\
\hline 34 & ASAHIMAS (42) & $-0,059126$ & 11 & \\
\hline 35 & GUDANG GARAM(43) & $-0,218137$ & 5 & \\
\hline 36 & CHAROEN P(44) & 0,038511 & 30 & \\
\hline 37 & KIMIA FARMA (48) & $-0,013688$ & & 19 \\
\hline & Jumlah $\mathrm{T}$ & & 157 & 546 \\
\hline
\end{tabular}

Sumber: data sekunder diolah,2012

Tabel 4

Rangking CAR Perusahaan Menaikkan dan Menurunkan Laba

\begin{tabular}{|r|l|r|r|r|}
\hline \multirow{2}{*}{ No } & \multirow{2}{*}{ Nama Perusahaan } & \multicolumn{3}{|c|}{2011} \\
\cline { 3 - 5 } & & \multicolumn{1}{|c|}{ CAR } & Naik & Turun \\
\hline 1 & Goodyear Indonesia & 0,107007 & & 13 \\
\hline 2 & Alumindo Ligh metal & 0,236426 & & 15 \\
\hline 3 & Unggul Indah Cahaya & $-0,009733$ & & 7 \\
\hline 4 & Astra Outpart & 0,081966 & 12 & \\
\hline 5 & Indomobil Sukses M & $-0,212900$ & & 1 \\
\hline 6 & Mulia Industrindo & $-0,133718$ & 2 & \\
\hline 7 & HM Sampurna & $-0,095783$ & 3 & \\
\hline 8 & Barito Pasifik & 0,073144 & 11 & \\
\hline
\end{tabular}




\begin{tabular}{|r|l|r|r|r|}
9 & Titan Kimia & 0,021829 & & 9 \\
\hline 10 & Unilever & $-0,047885$ & 5 & \\
\hline 11 & Semen Gresik & $-0,014647$ & & 6 \\
\hline 12 & Mayora Indah & 0,187724 & & 14 \\
\hline 13 & Asia Pasifik Fiber & 0,039509 & & 10 \\
\hline 14 & Gudang Gresik & $-0,063935$ & & 4 \\
\hline 15 & Tembaga & 0,011235 & & 8 \\
\hline & & & 33 & 87 \\
\hline
\end{tabular}

Sumber: data sekunder diolah, 2012

Kruskal-Wallis test untuk perusahaan yang melakukan manajemen laba menaikkan dan menurunkan laba.

2

$$
\mathrm{H}=\left\{12 / \mathrm{n}(\mathrm{n}+1) \sum \mathrm{Tj}^{2} / \mathrm{nj}\right\}-3
$$
$(\mathrm{n}+1)$

$$
\begin{aligned}
\mathrm{j}=1 & \\
& =\left\{12 / 15(15+1)\left(33^{2} / 5+87^{2} / 10\right)\right.
\end{aligned}
$$$$
-3(15+1)
$$

$$
\begin{aligned}
& =\{12 / 240(217,8+756,9)-48 \\
& =(0,05 \times 974,7)-48 \\
& =48,735-48 \\
& =0,735
\end{aligned}
$$

Berdasarkan perhitungan untuk mengetahui CAR antara perusahaan yang melakukan manajemen laba menaikkan dan perusahaan menurunkan diperoleh hasil nilai $\chi$ hitung sebesar 2,82767 dan 0,735 sedangkan nilai $\chi$-tabel sebesar
3,84146. Jadi nilai $\chi$-hitung dengan tingkat signifikan 0,05 antara nilai hasil lebih kecil dibandingkan dengan nilai $\chi$-tabel yaitu $\mathrm{H}<\chi^{2} \square, \mathrm{k}-1$ maka Ho tidak ditolak berarti nilai CAR untuk kedua kelompok sampel tidak terdapat perbedaan.

Hipotesis pertama dalam penelitian yaitu Cummulative abnormal return perusahaan yang melakukan manajemen laba lebih kecil dari pada Cummulative abnormal return perusahaan yang tidak melakukan menajemen laba. Untuk menguji hipotesis yang pertama dengan menggunakan two independen samples Kruskal-Willes test dengan tingkat signifikansi 5\%.

Berdasarkan perhitungan CAR antara perusahaan yang melakukan manajemen laba dengan perusahaan 
yang tidak melakukan manajemen labadi peroleh hasil nilai $\chi$-hitung sebesar 0,58989 dan 0,03137 sedangkan nilai $\chi$-tabel sebesar 3,84146. Jadi nilai $\chi$-hitung dengan tingkat signifikan 0,05 antara nilai hasil lebih kecil dibandingkan dengan nilai $\chi$-tabel yaitu $\mathrm{H}<\chi_{\square, \mathrm{k}-1}^{2}$ maka Ho tidak ditolak berarti nilai CAR untuk kedua kelompok sampel tidak terdapat perbedaan.

Hal ini didukung oleh penelitian Wahyuningsih (2007) yang menunjukkan bahwa tidak terdapat perbedaan reaksi pasar antara perusahaan melakukan manajemen laba dengan perusahaan tidak melakukan manajemen laba.

Hipotesis kedua yaitu Cummulative abnormal return antara perusahaan yang mempunyai akrual diskresioner menaikkan laba (income increasingdiscretionary accruals) lebih kecil dari pada Cummulative abnormal return perusahaan yang mempunyai akrualdiskresioner menurunkan laba (income decreasing discretionary accruals). Untuk menguji hipotesis yang kedua dengan menggunakan two independen samples test Kruskal-Walles dengan tingkat signifikansi 5\%.
Berdasarkan perhitungan untuk mengetahui CAR antara perusahaan yang melakukan manajemen laba menaikkan dan perusahaan menurunkan diperoleh hasil nilai $\chi$ hitung sebesar 2,82767 dan 0,735 sedangkan nilai $\chi$ tabel sebesar 3,84146. Jadi nilai $\chi$-hitung dengan tingkat signifikan 0,05 antara nilai hasil lebih kecil dibandingkan dengan nilai $\chi$-tabel yaitu $\mathrm{H}<\chi^{2}{ }_{\square, \mathrm{k} 1}$ maka Ho tidak ditolak berarti nilai CAR untuk kedua kelompok sampel tidak terdapat perbedaan.

Hal ini didukung oleh penelitian Wahyuningsih (2007) yang menunjukkan bahwa tidak terdapat perbedaan reaksi pasar antara perusahaan yang mempunyai akrual diskresioner menaikkan laba dengan perusahaan yang mempunyai akrual diskresioner menurunkan laba.

Penelitian ini berisi kajian tentang perusahaan yang melakukan praktek manajemen laba dengan menaikkan laba atau menurunkan laba. Analisis yang dimaksud dalam penelitian ini adalah mencoba mengkaitkan antara tindakan praktek manajemen laba yang dilakukan oleh perusahaan-perusahaan yang terdaftar di Bursa Efek Jakarta 
dengan reaksi pasar pada saat perusahaan tersebut mengumumkan laba.

Berdasarkan penelitian yang dilakukan dengan sampel 49 perusahaan diperoleh hasil sebagai penentuan hipotesis pertama gagal diterima, artinya selama periode pengamatan tidak ada perbedaan reaksi pasar atas pengumuman informasi laba antara perusahaan yang melakukan manajemen laba dengan perusahaan yang tidak melakukan menajemen laba. Hasil ini menunjukkan tidak adanya reaksi pasar atas praktek manajemen laba tersebut. Penjelasan yang mungkin atas hasil ini, bahwa pelaku pasar sebagian besar uninformed dan investor dalam berinvestasi belum menggunakan dasar laporan keuangan, investor tidak memberikan reaksi atas perbedaan tersebut. Selain itu, terdapat kemungkinan investor bereaksi secara lugas (naïve) dalam menginterpretasikan informasi yang diterimanya, sehingga walaupun laporan keuangan mengisyaratkan adanya praktek manajemen laba, pasar tidak memberikan reaksi.

Hasil penelitian ini sesuai dengan penelitian yang dilakukan oleh Khafid (2002) yang menyatakan tidak terdapat perbedaan reaksi pasar (CAR) atas pengumuman infomasi laba pada periode -6 sampai dengan 0 dan -3 sampai dengan +3 . Tetapi, hasil penelitian ini berbeda dengan hasil penelitian Salno (1999), Assih (2000) dan Nasir dkk (2000) yang menyatakan terdapat perbedaan reaksi pasar antara perusahaan perata dan bukan perata laba. Perbedaan penelitian ini dengan ketiga penelitian tersebut adalah: pertama, ketiga penelitian tersebut tidak menggunakan konsep akrual dalam mengukur manajemen laba dan kedua, penelitian-penelitian tersebut menggunakan sampel dari seluruh kelompok usaha. Adanya perbedaan tersebut dapat menjadi penyebab perbedaan hasil antara penelitian ini dengan ketiga penelitian tersebut.

Berdasarkan penelitian yang dilakukan dengan sampel 49 perusahaan diperoleh hasil sebagai penentuan hipotesis kedua gagal diterima, artinya selama periode pengamatan tidak terdapat perbedaan reaksi pasar antara perusahaan yang mempunyai akrual diskresioner menaikkan laba (income increasing discretionary accruals) dengan 
perusahaan yang mempunyai akrual diskresioner menurunkan laba (incomedecreasing discretionary accruals).

Hasil penelitian ini kemungkinan investor belum menggunakan analisis fundamental dan merupakan investor uninform, termasuk di dalamnya menganalisa adanya praktek manajemen laba dalam laporan keuangan, sehingga investor tidak menyadari sinyal yang diberikan oleh emiten melalui praktek manajemen laba mengenai kinerja perusahaan saat ini yang dapat lebih buruk (income increasing discretionary accruals) atau lebih baik (income decreasing discretionary accruals) dari yang dilaporkan. Hasil penelitian ini konsisten dengan penelitian yang dilakukan oleh Ardiati (2003) yang menyatakan tidak ada perbedaan return saham antara perusahaan yang mempunyai akrual diskresioner menaikkan laba dengan perusahaan yang mempunyai akrual diskresioner menurunkan laba.

\section{PENUTUP}

Penelitian yang menggunakan sampel 49 perusahaan manufaktur di
Bursa Efek Indonesia periode 20092010 ini bertujuan untuk memperoleh bukti baru mengenai hubungan antara reaksi pasar atas pengumuman informasi laba dengan manajemen laba.

Untuk menjawab permasalahan dalam penelitian ini pengujian dengan two independen samples test Kruskal-Walles dengan tingkat signifikansi 5\% dan menggunakan even windows -5 sampai +5 , hasil nilai rata -rata CAR kelompok mamajemen laba $\chi$-hitung sebesar 0,58989 dan 0,03137 serta nilai rata -rata CAR kelompok menaikkan dan menurunkan laba $\chi$-hitung sebesar 2,82767 dan 0,735 sedangkan nilai $\chi$-tabel sebesar 3,84146 , jadi nilai $\chi$ dengan tingkat signifikan 0,05 antara nilai hasil lebih kecil dibandingkan dengan nilai $\chi$-tabel maka apabila $\mathrm{H}<\chi_{\square, k-1}^{2}$ maka Ho tidak ditolak berarti nilai CAR untuk kedua kelompok sampel tidak terdapat perbedaan.

Berdasarkan hasil analisis di atas maka dapat ditarik kesimpulan berikut ini :

Cummulative abnormal return antara perusahaan yang melakukan 
manajemen laba dari pada Cummulative abnormal return perusahaan yang tidak melakukan menajemen laba tidak terdapat perbedaan, karena sebagian investor domestik masih merupakan investor uninformed yang mana belum begitu melihat pengaruh reaksi pasar sedangkan investor asing melihat bahwa pasar modal Indonesia merupakan pasar yang menarik karena price to book ratio masih rendah.

Cummulative abnormal return antara perusahaan yang mempunyai akrual diskresioner menaikkan laba (income increasing discretionary accruals) dari pada Cummulative abnormal return perusahaan yang mempunyai akrual diskresioner menurunkan laba (income decreasing discretionary accruals) tidak terdapat perbedaan karena sebagian investor domestik masih merupakan investor uninformed yang mana belum begitu melihat pengaruh reaksi pasar sedangkan investor asing melihat bahwa pasar modal Indonesia merupakan pasar yang menarik karena price to book ratio masih rendah.
Implikasi yang diperoleh dari hasil penelitian tahap kedua menunjukkan bahwa pasar modal di Indonesia (BEI) belum efisien masih dalam bentuk setengah kuat.

\section{Keterbatasan Penelitian Dan} Saran

Penelitian ini mempunyai beberapa keterbatasan dan saran yang diberikan untuk penelitian berikutnya. Kelemahan atau kekurangan yang ditemukan setelah dilakukan analisis dan interpretasi data adalah dalam penelitian ini menggunakan confenience sampling yang merupakan non probability sampling maka hasil penelitian tidak dapat digeneralisasi untuk perusahaan manufaktur.

Saran untuk penelitian selanjutnya diharapkan dapat melengkapi keterbatasan penelitian dengan mengembangkan beberapa hal sebagai berikut:

Perlunya mempertimbangkan model berbeda selain Kaszik Model yang akan digunakan dalam menentukan discretionary accrual sehingga dapat melihat adanya manajemen laba dengan sudut pandang yang berbeda. 
Penelitian selanjutnya yang mungkin berpengaruh terhadap diharapkan menambahkan variable- manajemen laba.

variabel lain misalnya variabel size

\section{DAFTAR PUSTAKA}

Apriani, Lisia, 2005, Reaksi Pasar Terhadap Pengumuman Kenaikan /Penurunan Dividen (Studi Empiris pada Perusahaan Utilitas Publik dan Perusahaan dalam Industri tidak di Regulasi), Simposium Nasional AkuntansiVIII.

Assih, Prihat., dan M. Gudono, 2000, "Hubungan Tindakan Perataan Laba dengan Reaksi Pasar atas Pengumuman Informasi Laba Perusahaan yang Terdapat di Bursa Efek Jakarta", Jurnal Riset Akuntansi Indonesia, Januari, hal 35-53.

Ball, Ray and Philip Brown, 1968, “An Empirical Evaluation of Accounting Income Number", Journal of Accounting Research. Vol 6

Fabozzi, Frank J, 1995, Manajemen Investasi, Prentice-Hall, Inc Fudenberg.

Fama, E.F. 1970. "Efficient Capital Market: A Review of Theory and Empirical Work”, Journal of Finance, Vol 25. pp. 383-417

Fudenberg, Drew and Jean Tirole. 1995. "A Theory of Income and Devidend Smoothing Based on Incumbency Rates". Journal of Political Economy. February. pp. 75-93.

Ikatan Akuntan Indonesia. 2009. PernyataanStandar Akuntansi Keuangan, Penyajian Laporan Keuangan, Jakarta.

Husnan, Suad, 2005, Dasar-dasar Teori Portofolio dan Analisis Sekuritas, UPP AMP YKPN, Yogyakarta.

Jogiyanto, H.M. 2000. "Teori Portofolio dan Analisis Investasi”. Edisi 2. BPFE, Universitas Gajah Mada. Yogyakarta.Samsul Muhammad, 2006, Pasar Modal dan Manajemen Portopolio, Erlangga, Jakarta.

Keller,Gerald and Brian Warrack, 2003, Statitics for Managemend and Economics $6^{\text {Th }} e d$, Duxbury Press, An International Thomson Publishing Company: Pacific Brove, CA 93950.

Pertiwi, Ayu, Diah, 2010, Analisis Pengaruh Earning Management Terhadap Nilai Perusahaan Dengan Peranan Praktik Corporate Governance Sebagai 
Moderating Variabel Pada Perusahaan yang terdaftar Di Bursa Efek Indonesia 2005-2008, Skripsi, Universitas Diponegoro, Dipublikasikan.

Ningsaptiti, Restie, 2010, Analisis Pengaruh Ukuran Perusahaan Dan Mekanisme

Corporate Governance Terhadap Manajemen Laba, Skripsi, Universitas Diponegoro, Dipublikasikan.

Schipper, K.1989. Earning Management. Accounting Horizon. Vol 3

Scott, W.R. 1997. Financial Accounting Theory. Prentice Hall Inc. New Jersey.

Siti, Munfiah, Hidayati dan Zulaikha, 2003. "Analisis Perilaku Earning Management: Motivasi Minimalisasi Income Tax," Simposium Nasional Akuntansi VI.

Sulistyanto, Sri, H, 2008, Manajemen Laba Teori dan Model Empiris, Grasindo, Jakarta.

Sugiri. 1998. "Earning Management, Teori, Model, dan Bukti Empiris", Telaah.

Sopa, Sugiarto. 2003. "Perataan Laba dalam Mengantisipasi Laba Masa Depan

Perusahaan Manufaktur yang Terdaftar di Bursa Efek Jakarta". SimposiumNasional Akuntansi VI.

Supranto, J, 2010, Metode Ramalan Kuantitatif Untuk Perencanaan Ekonomi dan Bisnis, Rineka Cipta, Jakarta.

, 2010, Metode Riset Aplikasi dalam Pemasaran, Rineka Cipta, Jakarta.

Jakarta.

Subramanyam, K. 1995. "The Pricing of Discretionary Accruals". Journal of Accounting and Economics. Vol 22 August-December. pp. 249-281.

Telaumbanua, Binsar, I. K., dan Sumiyana, 2008, Event Study: Pengumuman Laba Terhadap Reaksi Pasar Modal, Jurnal Manajemen Teori dan Terapan. Wahyuningsih, Retno, Dwi, 2007, Hubungan Praktik Manajemen Laba Dengan Reaksi Pasar Atas Pengumuman Informasi Laba Perusahaan Manufaktur Di Bursa Efek Jakarta, Tesis, Universitas Diponegoro, Dipublikasikan. 